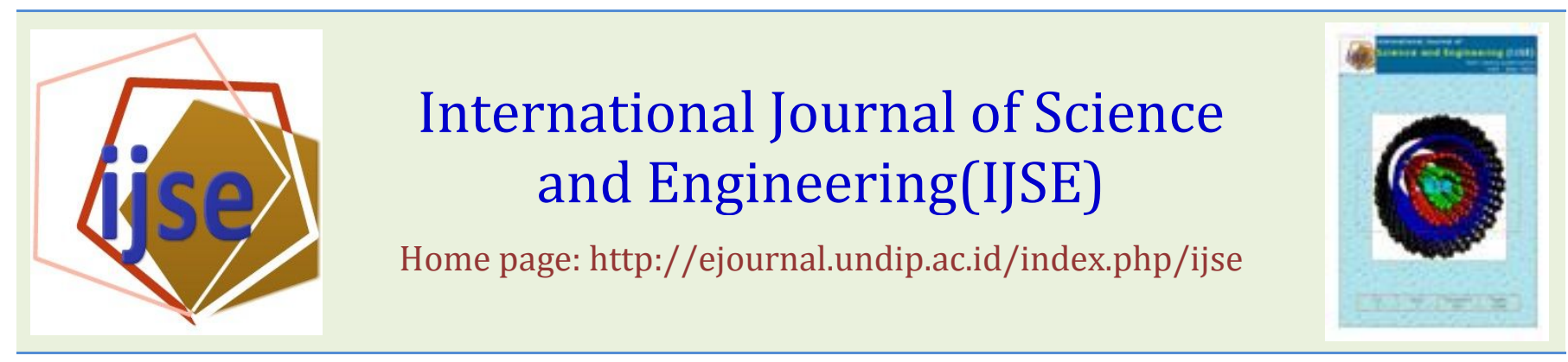

\title{
Potency of Mahakam Delta in East Kalimantan, Indonesia
}

\author{
Zairin Zain $^{1)}$, S. Hutabarat ${ }^{2)}$, B. Prayitno ${ }^{2)}$, Ambaryanto ${ }^{2)}$ \\ 1)Department of Transportation of East Kalimantan Province, Jl. Kusuma Bangsa Samarinda Kalimantan Timur 75000 \\ 2)Fisheries and Marine Science Faculty of Diponegoro University, Jl. Prof. Soedarto, SH. Campus UNDIP Tembalang Semarang 50275 \\ Email: zairinzain59@yahoo.co.id
}

\begin{abstract}
Mahakam Delta is not only utilized for fishery activities but also for several industrial purposes such as coal and oil mining, shipping and timber. The objective of this paper is to provide information in term of the potency of Mahakam Delta located in East Kalimantan province, Indonesia. The study was conducted in Mahakam Delta, East Kalimantan Province, Indonesia. Participatory rural appraisal is a group of methods to collect information in a participatory fashion from rural communities. The method employed in this research was descriptive analysis describing the environmental potency found in Mahakam Delta. Massive conversion of mangrove forest particularly Nypa (Nypa fruticans) area into pond has driven conflict among related stakeholders on the utilization of natural resource and land which subsequently impacts on the fish and shrimp source regeneration, loss of ecological functions of mangrove forest for feeding, nursery and spawning ground of fish and other organisms. Besides of fisheries, oil and gas activity also exists in Mahakam Delta. Mahakam Delta is regarded as important area due to the largest producer of oil and gas mining. Thus, oil and gas industry is the most reliable sector that contributes to the economic development of Kutai Kartanegara district. As a resource provider, Mahakam Delta ecosystem provides various resources for livelihoods. As a life-support service provider, Mahakam Delta ecosystem provides habitat and ideal environment to support variety of living kinds. As a convenience provider, Mahakam Delta ecosystem provides unique and interesting recreation site. As a protector from natural disaster, Mahakam Delta ecosystem is able to protect human kinds from natural disaster threatening coastal area.
\end{abstract}

Keywords: potency; Mahakam Delta; pond; mangrove; oil and gas mining

Submission: March 20, $2014 \quad$ Correction: April 10, 2014

Accepted: April 15, 2014

Doi: $10.12777 /$ ijse.6.2.126-130

[How to cite this article: Zairin Zain, S. Hutabarat, B. Prayitno and Ambaryanto. 2014. Potency of Mahakam Delta, East Kalimantan, Indonesia, International Journal of Science and Engineering, 6(2),126-130. Doi:10.12777/ijse.6.2.126-130]

\section{INTRODUCTION}

East Kalimantan is acknowledged as a province with wide variety of coastal system that generally influenced by human interference. Many exploration activities of oil and gas mining could be seen in many part of coastal area in East Kalimantan. However, nature coastal area still remains in other part of the region. Rivers in East Kalimantan has wide area of watershed where the river length could reach up to $400 \mathrm{~km}$ (Detrieux, 2001; Fatawi and Mori, 2000).

Mahakam Delta is one of watershed area in East Kalimantan and formed through sedimentation process. This region is divided into four vegetation zones, namely: perennial tree of low land tropical forest, palm tree and mixed lowland forest, Nypa mangrove forest and swamp forest. Since from tertiary period, rivers in East Kalimantan have developed to form delta system and this process still continue. Delta has been formed in many varieties starting from prograding deltas (such as Mahakam Delta) up to delta with domination of tidal areas such as Berau Delta. The formation of many ecosystems with abundant biodiversity (including coral reefs, seagrass, mangrove and fish) is strongly influenced by the abiotic condition such as the presence of suspended sedimentation (turbidity), nutrient availability, current and tidal dynamic. However, marine habitats such as coral reef and seagrass bed are not found in Mahakam Delta due to lack of water quality and oceanography factors (Bourgeois et al., 2002; Detrieux, 2001).

Mahakam Delta is characterized by rainfall rate of more than $2.5 \mathrm{~m} / \mathrm{sec}$, flowing water and sediment over $900 \mathrm{~km}^{2}$ along Mahakam River to its mouth at Makassar Strait which has strong current of north and south. Several mouths of Mahakam Delta are estuaries zone with sand deposit found in the middle and south zone. Stated that erosion occurs at the north side and the lowest sand is at the south side of Mahakam Delta with wide and muddy coastal. Mangrove ecosystem and small area of sea grass and coral reef can be found in coastal area. Besides, Mahakam watershed creates estuaries characteristic at the river mouth and Mahakam Delta area. The complexity of ecosystem produces high resources both in fossil 
resource (coals, oil and natural gas) or fisheries resources in the coastal area (Dutrieux, 1991; Syamsuri, 2001; Bourgeois et al., 2002; Sidik, 2008; Bengen et al., 2003; Atmoko and Sidiyas, 2008; Nursigit et al., 2013).

According to the information above, the objective of this paper is to provide information concerning on the potency of Mahakam River Delta in Kalimantan Indonesia.

\section{RESEARCH METHOD}

The study was conducted in Mahakam Delta, East Kalimantan Province, Indonesia. The area of Mahakam Delta consists of big and small estuaries areas which gather at the mouth of Mahakam River. Geographically, the area is located on $170^{\circ} 15^{\prime} 0^{\prime \prime}-170^{\circ} 36^{\prime} 46.2^{\prime \prime}$ east longitude and $00^{\circ} 20^{\prime} 48^{\prime \prime}-00^{\circ} 48^{\prime} 49.8^{\prime \prime}$ south latitude. Participatory rural appraisal is a group of methods to collect information in a participatory fashion from rural communities (Samad et al., 2013).

The method employed in this research was descriptive analysis describing the environmental potency found in Mahakam Delta. The location of Mahakam Delta in equator area determines high annual temperature which remains constant at $26-28^{\circ} \mathrm{C}$ (tabulation result of $\mathrm{BMKG}$ ) with minimum annual variance and limited diurnal temperature. Tidal current occurs due to combination of diurnal and semi-diurnal component ranging about $2.5 \mathrm{~m}$ height and low wave energy. This tidal current is combined with high current from Mahakam River $(1,500$ $\mathrm{m}^{3} / \mathrm{sec}$ ).

Total population in Mahakam Delta area is 178.776 people with the highest population area is Muara Badak Ilir village by 13.013 people. The average population density of Mahakam Delta is 26.34 people $/ \mathrm{km}^{2}$. The most dense area is Muara Jawa Ulu village by 352.19 people $/ \mathrm{km}^{2}$. More detail, total population and density of Mahakam Delta could be seen in Table 1.

Tabel 1. Total and density population of Mahakam Delta in 2009

\begin{tabular}{lrrr}
\hline \multicolumn{1}{c}{ Sub-district } & \multicolumn{1}{c}{$\begin{array}{c}\text { Area } \\
\left(\mathrm{km}^{2}\right)\end{array}$} & $\begin{array}{c}\text { Total } \\
\text { population } \\
\text { (people) }\end{array}$ & $\begin{array}{r}\text { Population density } \\
(\text { people/km }\end{array}$ \\
\hline 1. MuaraBadak & 939.09 & 39,841 & 42.43 \\
2. Anggana & $1,798.80$ & 32,789 & 18.23 \\
3. Sanga-sanga & 233.40 & 17,611 & 75.45 \\
4. MuaraJawa & 754.50 & 33,835 & 44.84 \\
5. Samboja & $1,049.90$ & 54,700 & 52.3 \\
\hline Total & $4,775.69$ & 178,776 & 231.95 \\
\hline
\end{tabular}

Source: Statistic of Kutai Kertanagara District 2010

Mahakam Delta lies on four sub-districts, i.e. Anggana, Muara Jawa, Muara Badak, and Samboja sub-district. In accordance to open coastal area, the community of Mahakam Delta consists of local and migrant resident inhabitant esp. Bugis ethnic from South Sulawesi. The first ethnic varies from Banjar, Jawa, Batak, East Nusa Tenggara and Chinese. In term of economic point of view, Mahakam Delta is considered as very important area due to oil and gas resources in Indonesia. Mahakam Delta is also well known with shrimp pond resources which important for regional government. However, due to geographic, biophysics and geologic condition and lack of governance or regulation for managing the resources, Mahakam Delta is characterized as open access resource.

Mahakam Delta is now widely used by community for pond activity (Figure 1). In general the Mahakam Delta pond activities can be perceived extensive with a primitive technique according to pond modelling standards available in Indonesia. Ponds in the Mahakam Delta were categorized irregular from their type and form (rectangular, cube, and hexagonal). Each pond had average area of 1.5-50 ha/unit with the average pond area of 5.0 ha (Noryadi and Syafei, 2008; Asikin, et al., 2012). In accordance to the land use, Mahakam Delta is now classified into five groups, i.e.: pond, open area, mangrove forest (mangrove, palm), industrial and residential.

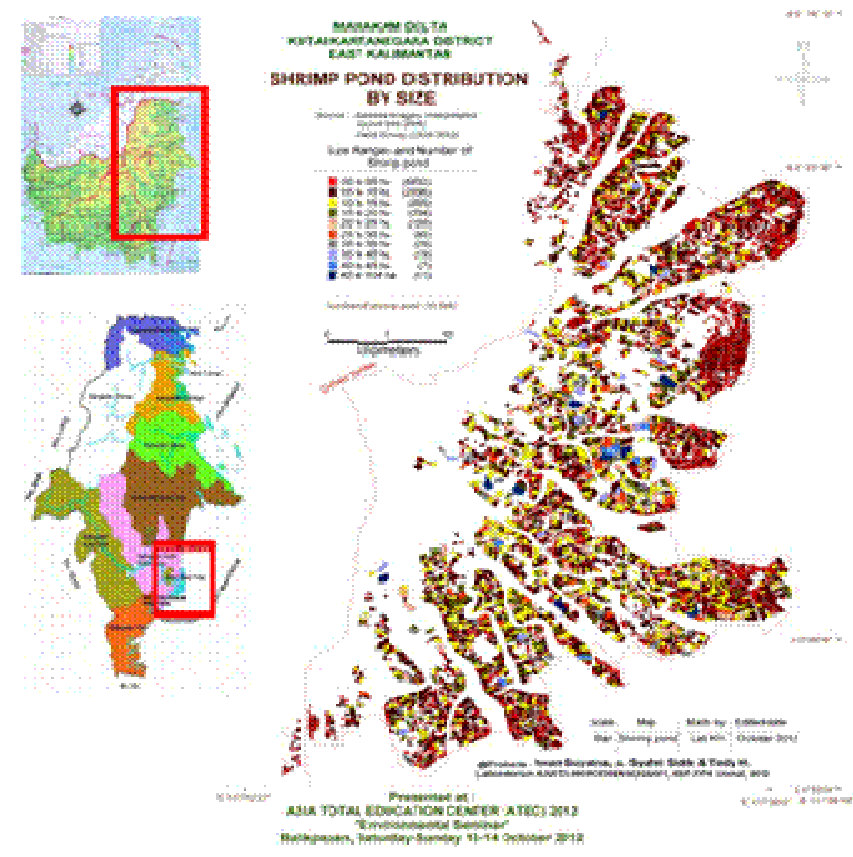

Figure 1. Map of pond area in Mahakam Delta (Source: Suyatna et al., 2012)

\section{III.RESULT AND DISCUSSION}

Mahakam Delta is not only utilized for fisheries activity but also for several industries such as coal and oil mining, shipping and timber. Most of fisheries activities are designed for pond farming. Mahakam Delta covers 107,221 ha comprising area of coastal forest 49,309 ha and pond 57,912 ha with 10,645 units. This number represents that pond area is bigger than the coastal forest. One of coastal resource and productive ocean which is significantly exploited is Mahakam Delta located in East Kalimantan province. This area has specific condition of bio-geophysics with approximately of $1,500 \mathrm{~km}^{2}$.

In the early 1980s, part of Mahakam Delta is covered by a dense of Nypa and mangrove vegetation. Conversion area has occurred for over 20 years which changes the land uses of 80,000 ha of Mahakam Delta into pond area. The conversion from mangrove area into pond area tends to increase. In addition, heavy land use changes from mangrove area, esp. Nypa (Nypa fruticans), into pond area causes conflict of interest in utilizing land and resource among stakeholders. 
Moreover, this conversion threatens the existence and quality of resource and environment of Mahakam Delta. In some extent, if some efforts are not immediately addressed to overcome this serious problem, the ecosystem function of Mahakam Delta will loss and no longer supports the sustainability management. Thus, integrated ecosystem management of Mahakam Delta is very important to take place.

Fundamental change includes micro climate condition particularly on rapid changes of temperature, salinity, wind and evaporation. Catchment or filter availability of open area towards pollutant and mud becomes low. Furthermore, the area also vulnerable to erosion and abrasion leads to high turbidity in the surrounding area which characterized by sedimentation over water flowing area. This condition reduces the ecosystem function of mangrove as nursery ground, feeding ground, fishing ground, etc.

Conversion of mangrove forest into pond, agriculture, estate, oil and gas mining or residential have negative impact on the regeneration of fish and shrimp. Besides, this condition leads to the decreasing of ecological value of mangrove as a place that provides food, nursery, spawning fish or other organisms. Thus, many species of flora and fauna which associates with mangrove ecosystem will extinct and endanger the balance of coastal ecosystem.

In order to meet their desired, farmers cut down mangrove forest placed in Mahakam Delta are to be converted for pond area. As a consequence, this will endanger the environmental balance along with the decreasing quality of ecological function of mangrove forest. If it continually occurs, sooner or later the ecological damage of Mahakam Delta will be more severe which in turn leading to the collapse of the entire pond area particularly in this region.

Besides of fisheries, oil and gas activity also exists in Mahakam Delta (Figure 2). Oil and gas industry is the most reliable sector that contributes to the economic development of Kutai Kartanegara. Mahakam Delta is regarded as important area due to the largest producer of oil and gas mining. Thus, it has important impact for the development of this area and its surrounding.

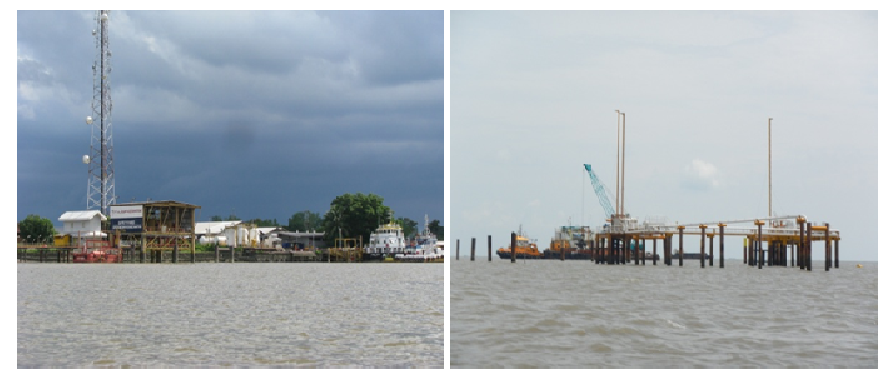

Figure 2. Oil and gas industry in Mahakam Delta (Source: Author documentation)

Mahakam Delta is a unique and productive ecosystem with abundant resources. Under appropriate management, this potency could significantly increase the economic value both regional and national. Administratively, Mahakam Delta belongs to Kutai
Kartanegara district, Province of East Kalimantan. It lies between $019^{\prime}-0^{\circ} 55^{\prime}$ of South Latitude and $117^{\circ} 15^{\prime}-117^{\circ}$ 40' of East Longitude. As coastal ecosystem, Mahakam Delta with $1,500 \mathrm{~km}^{2}$ is naturally covered by Nypa as dominant vegetation followed by api-api (Avicenniaspp), and mangrove tree (Rhizohoraspp) (Dutrieux, 2001).

Mahakam Delta is acknowledged as the widest Nypa area around the world, abundant biological productivity which supplied by organic material from land area through river flow. Thus, the ecosystem is rich of fish, shrimp and crab. Besides of its biological resource, Mahakam Delta is also rich of non-biological resource such as oil and gas. Both of potential resources makes Mahakam Delta has very important role in the economic development based on biological resource (fisheries) and non-biological resources (oil and gas mining) in East Kalimantan province and Kutai Kartanegara district. Those two resources have different utilization but connected among others. Thus, the principal of ecosystem linkages should be implemented in order to obtain the optimum and sustainable utilization.

Mahakam Delta is a coastal ecosystem with specific geological and ecological condition characterized by delta and estuarine. This kind of ecosystem is very ideal for the growth of mangrove. The economic value of mangrove resource belongs to long term economic value (characterized by low discount rate) while oil and gas resource has short term economic value (characterized by high discount rate). Despite of its un-significant economic value, mangrove has remarkable contribution to the sustainability of coastal area. Mahakam Delta is dominated by mangrove ecosystem created from long term sedimentation process of $770 \mathrm{~km}$ long Mahakam river with water discharge at $1,500 \mathrm{~m}^{3}$ per second and contain suspended solid concentration up to $80 \mathrm{mg} / \mathrm{l}$. Those conditions very influence the formation of mangrove vegetation in Mahakam Delta (Powell and Osbeck, 2010). In general, covered vegetation in Mahakam Delta is divided into several zones, namely:

1. Pedada or Perepat (Sonetarria alba-avicennia sp). This zone is the outer area with a thickness varies from 100 to $500 \mathrm{~m}$. Perepat (Sonneratiaalba) dominates this area and followed by api-api (Avicennia $s p$ ). In 1980, api-api covered about 8,322 ha in Mahakam Delta and decreased up to 1,716 ha in 1999 due to land conversion from mangrove to pond activity.

2. Mangrove Zone (Rhizophora sp). This zone is generally found in particular location on lower delta and islands such as Tunu and Seleta islands including several places in Muara Tambora.

3. Transition Zone. This zone covers much vegetation such as api-api (Avicennia sp), bakau (Rhizhophora sp), tancang (Bruguiera parviflora), nyirih (Xylocarpus granatum), and nipah (Nypa fruticans). This zone is thicker than zone of sonneratia alba-avicennia sp.

4. Nypa Zone. Nypa (Nypa fruticans) zone is a fairly wide zone in Mahakam Delta accounted by $50 \%$ of the total delta area. In 1980, the area reached up to 58,061 ha and declined up to 11,037 ha in 1999 due to land conversion into aquaculture area. 
5. Nibung Zone. This zone is recognized as tidal mangrove zone grown by dungun (Heritiera littoralis), tancang or matabuaya (Bruguiera sexangula) nibung (Oncosoerma sp) and Buta-buta (Excoecaria agallocha). This area covered 18,248 ha in 1980 and declined up to 11,834 ha in 1999 .

Mahakam delta ecosystem has four main functions described below. As a resource provider, Mahakam Delta ecosystem provides variety of resources for livelihoods. As a life-support service provider, Mahakam Delta ecosystem provides habitat and ideal environment to support variety of living kinds. As a convenience provider, Mahakam Delta ecosystem provides unique and interesting recreation site. As a protector from natural disaster, Mahakam Delta ecosystem is able to protect humankinds from natural disaster threatening coastal area.

The four main functions of Mahakam Delta ecosystem mentioned above makes this site very interesting and promising for the development of human interest. This ecosystem is not only exploited on the resources but also to be utilized as aquaculture, transportation and residential. Unfortunately, the exploitation conducted so far has caused some disasters which threatened the ecosystem's ability on providing natural resources and also reduced the ability on disaster mitigation in coastal area. It impacts on the loss of spawning area, nursery ground and feeding ground for various marine habitats and decreasing of fish number.

Another impact of this phenomenon is the loss of physical functions of Mahakam Delta such as barriers to erosion, wave dampers and breakers, sea water intrusion and pollution absorbent. This phenomenon occurs due to destructive practice on the utilization of natural resource and un-environmentally friendly area development management such as large-scale logging and conversion of mangrove forest. Some efforts should be addressed to protect and rehabilitate the degraded ecosystem especially on their function as natural resource provider and disaster mitigation reduction.

Mahakam Delta ecosystem is influenced by land and water area that are interconnected with each other. This ecosystem is an integral set of biological and nonbiological component which functionally interact to form a system. One of this interconnection could be seen from the movement of river water, river water run-off and ground water run-off which contained some particle (such as nutrient, sediment and pollutant) which finally ends at Mahakam Delta ecosystem.

The pattern of sedimentation and abrasion is also influenced by water movement of land or ocean. In addition, water movement influences the movement of marine habitats such as plankton, fish and shrimp and also the pollutant. Mangrove as the main ecosystem in Mahakam Delta has important biological roles to maintain the sustainability of productivity and availability of natural resources in coastal zone.

Mangrove ecosystem is also used for nursery and spawning ground of some marine habitats such as shrimp, fish and shell fish (Bengen et al., 2003). Mangrove ecosystem is the main living and culture source for community living in coastal area who utilizes this ecosystem for producing food, medicines, tannin, charcoal and construction material. This ecosystem also has important role in preventing coastal area and it's residential from wave and abrasion. Thus, direct or indirect ecosystem management practiced in Mahakam Delta should consider ecological connectivity between land and ocean.

Mahakam Delta is dominated by mangrove habitat grown throughout estuary and attaches the outer coastal in the eastern side. Mahakam Delta is an ideal habitat for mangrove as it belongs to tidal area and an area which mixes water flowing from river and ocean. Tidal area is approximately $2.5 \mathrm{~m}$ and the suspended particulate matter is approximately $160 \mathrm{mg} / \mathrm{l}$.

Mangrove forest is more frequently flooded by water compared to swamp forest and dry land forest. Mangrove forest only consists of trees not higher than $25 \mathrm{~m}$, others vegetation are rarely found except a new seedling growth of the same variety. This is due to regular tidal flooding upon mangrove forest. Bourgeois et al. (2002) stated that Mahakam Delta is formed through sedimentation process of Mahakam River, the longest river in East Kalimantan. It is divided into four vegetation zones, namely: perennial tree of low land tropical forest, palm tree and mixed lowland forest, Nypa mangrove forest and swamp forest. Together, Nypa swamp forest and mangrove forest is jointly termed as mangrove forest as their spreading depends on the presence of sea water. It covers about $60 \%$ area of delta. The ability of strong root system of mangrove forest to prevent the coastal area from waves and coastal abrasion makes this area as buffer zone. In Kalimantan, eight mangrove families have been recorded i.e. rhizophoraceae, Avicenniaceae, Sonneratiaceae, Combretaceae, Meliaceae, Myrsinaceae, Euphorbiaceae, and Palmae. The predominant genus in Mahakam Delta is rhizopora, bruguiera, avicennia, sonneratia, lumnitzera, xlyocarpus, aegicera, exocoeria, and nypa (Mackinnon et al., 2000).

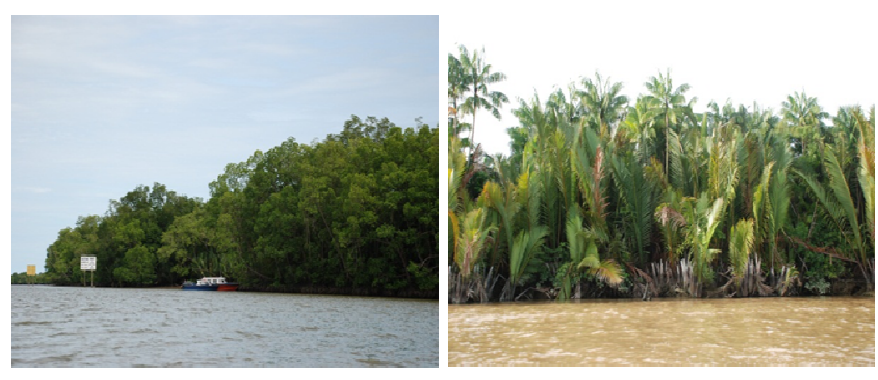

Fig 3. Mangrove ecosystem in Mahakam Delta Source: Author documentation

The environment quality of Mahakam Delta has decreased continuously leading to the serious disaster status. This condition is the result of ecosystem management which does not respect the principle of integrated and sustainable management; for example, the large-scale conversion from mangrove area into other purpose such as pond farming.

Land use changes from mangrove forest into aquaculture brings serious impact on the eco-biophysical 
process such as erosion (abrasion), loss of coastal green belt that serves as buffer and protector from strong waves, decreasing of water quality, declining of biological diversity, loss of habitat, spawning area, nursery ground and feeding ground for various fishes, shrimps and other marine habitats.

Massive mangrove conversion especially Nypa (Nypa fruticans) into pond has driven conflict among related stakeholders on the utilization of natural resource and the area. Some of those are conflict between pond farmer and traditional fishermen. Conflict between pond farmer and oil and gas mining industry also occurs due to conversion area has extended to mining area. In addition, conversion also threatens the availability and the quality of natural resource and environment surrounds Mahakam Delta. This serious problem should be immediately addressed to prevent the loss of ecological and economical value of Mahakam Delta and also to avoid inappropriate management practice. Thus, some integrated efforts and actions from all related stakeholders are needed to take place to achieve the sustainability of Mahakam Delta.

Mahakam Delta has a good potential for further development. The main strength lies on the abundant sources of oil and gas and non-oil and gas. Those resources become the main living source of community living in Mahakam Delta to meet their living needs. They organize their resources as oil and gas stock, economic fisheries product, recreation site by exploring the beauty of Nypa and mangrove forest.

The constraint on the development of Mahakam Delta is the degradation of natural resource and land use conflict among stakeholders. This conflict arises due to lack of spatial planning of Mahakam Delta as strategic site of Kutai Kartanegara district and East Kalimantan province as mandated in legal regulation governing the utilization of Mahakam Delta i.e. Act No. 26 year 2007 concerning Spatial Planning and Act No. 27 year 2007 concerning Management of Coastal Zone and Small Islands.

Mahakam Delta has all components for improved management. Sustainability management that delivers economic advantage for all community and stakeholders could be obtained by maximizing strength and opportunity and minimizing weakness and threats.

\section{CONCLUSION}

Massive conversion of mangrove forest particularly Nypa (Nypa fruticans) area into pond has driven conflict among related stakeholders on the utilization of natural resource and the area. It impacts on the fish and shrimp source regeneration, loss of ecological functions of mangrove forest for feeding, nursery and spawning ground of fish and other organisms.

Besides of fisheries, oil and gas activity also exists in Mahakam Delta. Mahakam Delta is regarded as important area due to the largest producer of oil and gas mining. Thus, oil and gas industry is the most reliable sector that contributes to the economic development of Kutai Kartanegara. As a resource provider, Mahakam Delta ecosystem provides various resources for livelihoods. As a life-support service provider, Mahakam Delta ecosystem provides habitat and ideal environment to support variety of living kinds. As a convenience provider, Mahakam Delta ecosystem provides unique and interesting recreation site. As a protector from natural disaster, Mahakam Delta ecosystem is able to protect humankinds from natural disaster threatening coastal area.

\section{REFERENCES}

[1] Asikin, A,N., S. Hutabarat, Y. S. Darmanto and S. B. Prayitno. 2012.Strategy of quality improvement of pond shrimp post harvest management (Penaeus monodon F.) in Mahakam delta (case study). Int. J. Sci. Eng., 3 (2): 15-20.

[2] Atmoko, T., and K Sidiyasa. 2008. Characteristic of vegetation of probosvis Monkey' (Nasalis larvatus Wumb) Habitat at Mahakam Delta, East Kalimantan. Jurnal Penlitian Hutan dan Konservasi Alam 5 (4): 307-316.

[3] Bengen, Dietriech G., R. R. Rini Budi Sayekti, N. Makinuddin, P. Santoso, Das'at and T. Gunawan. 2003. Reality and Issues of Resource and Environment in Mahakam Delta, Rapid Appraisal, Proyek Pesisir PKSPL-IPB, Bogor; Bapedalda Kabupaten KutaiKartanegara; Coastal Project in East Kalimantan; USAID; Total Fina Elf E\&P Indonesia; The Nature Conservancy, Bogor, Indonesia. $10 \mathrm{pp}$

[4] Bourgeois, Robin, A. Gouyon, F. Jesus, P. Levang, W. Langeraar, F. Rahmadani, E. Sudiono and B. Sulistiadi. 2002. A Socio Economic and Institutional Analysis of Mahakam Delta Stakeholders, Final Report, TOTAL, Jakarta. 107 pp.

[5] Dutrieux, E. 2001. The Mahakam Delta Environment, From the 80s up to now: A Synthesis of a 15-Years Investigation, (Eds: T. Kusumastanto, D. G. Bengen, B. Widigdo and I. Soeseno), In Optimizing Development and Environmental Issues at Coastal Area: Problem and Solution for Sustainable of Mahakam Delta, Jakarta, Indonesia, Pertamina-Total Fina Elf E\&P Indonesia, PKSPL-IPB, Department of Marine Affairs and Fisheries, pp. 63 - 65

[5] Dutrieux, E. 1991. Studi of Ecological functioning of the Mahakam Delta (East Kalimantan Indonesia). Estuaries Coastal and Shelf Science 32: 415-420.

[6] Fatawi, M., and T. Mori. 2000. Description of Forests and Forestry in East Kalimantan. Rainforest Ecosystems of East Kalimantan Ecological Studies Volume 140. pp 3-12.

[7] Mackinnon, K.G. Hatta, H. Halim and A. Mangalik. 2000. Ecology Borneo. Indonesia Book Series ecology. Prenhallindo Jakarta. pp.972.

[8] Noryadi and Syafei. 2008. Alternative Development Model Wanamina (Shilvo fisheries). Program PMD. The research report. Faculty of Fisheries and Marine Sciences. Mulawarman University, Samarinda.

[9] Nursigit, L. Sya'rani, and A. Suryanto. 2013. Zonation compatibility on forest mangrove area in Delta Mahakam, East Kalimantan Indonesia. International Journal of Waste Resources 3 (1): 47-55.

[10] Powelln, N., and M. Osbeck, 2010. Approaches for understanding and embedding stakeholder realities in mangrove rehabilitation processes in Southeast Asia: lessons learnt from Mahakam Delta, East Kalimantan. Sustainable Development 18 (5): 260-270.

[11] Sidik, A. S. 2008. The Changes of Mangrove Ecosystem in Mahakam Delta, Indonesia: A Complex Sosial-Envinronmental Pattern of Lingkages in Resources Utilization. Paper Presented at The South China Sea Conference. Sustaining Ocean Productivities, Maritime Communities and the Climate, Kuantan. 1-20.

[12] Statistic Office of Kukar District. 2010. Statistic of Kukar District 2012. BPS Kabupaten Berau, Tanjung Redeb.

[13] Suyatna, I., A. S. Sidik and H. Tedi. 2012. Laboratorium Kartohidrooseanografi, MSP FPIK, UNMUL, Samarinda.

[14] Syamsuri, A. 2001. Potency and Problem Occurs in Mahakam Delta, (Eds, Tridoyo Kusumastanto, Dietriech G. Bengen, Bambang Widigdo and Imam Soeseno), In: International Workshop for Optimizing Development and Environmental Issues at Coastal Area: Solution for Sustainable Management of Mahakam Delta., Jakarta, Indonesia, Pertamina-TOTAL FINA ELF E\&P Indonesie, PKSPL-IPB, Department of Marine Affairs and Fisheries, pp. 27-30. 